Article

\title{
Adoption of Organic Farming as an Opportunity for Syrian Farmers of Fresh Fruit and Vegetables: An Application of the Theory of Planned Behaviour and Structural Equation Modelling
}

\author{
Irwa Issa and Ulrich Hamm * \\ Department of Agricultural and Food Marketing, University of Kassel, 37213 Witzenhausen, Germany; \\ issa.irwa@gmail.com \\ * Correspondence: hamm@uni-kassel.de
}

Received: 4 September 2017; Accepted: 2 November 2017; Published: 4 November 2017

\begin{abstract}
Exporting organic fresh fruit and vegetables (FFV) to the European Union could represent a great opportunity for Syrian farmers and exporters. Yet, the organic sector in Syria is comparatively young and only a very small area of FFV is organically managed. To date, little is known about Syrian farmers' attitudes towards organic FFV production. Therefore, the aim of this study was to explore the intentions and attitudes of Syrian farmers of FFV towards organic farming and how likely they are to convert their farms to organic production within the next five years. Using a two-stage cluster sampling procedure, 266 conventional farmers of FFV in 75 villages located in different districts of Syria's coastal region were selected for this survey. Data was collected through face-to-face interviews by a project partner in Syria (Citrus Fruit Board in Tartous) from December 2012 until mid-May 2013. We used the Theory of Planned Behaviour as theoretical framework and Partial Least Squares Path Modelling as the main tool for data analysis. The results show that most farmers used at least one of the practices that are also part of certified organic production (throughout this article, the term organic agriculture, farming, and/or production always refer to certified organic agricultural production), and hold strong positive attitudes and intentions to adopt organic production within the next five years.
\end{abstract}

Keywords: organic agriculture; farm conversion; theory of planned behaviour; structural equation modelling

\section{Introduction}

Over the last two decades, organic production has attracted increasing attention all over the world. While only about 11 million ha were organically certified in 1999, this figure reached 50.9 million ha in 2015. Almost 2.4 million producers in the world were reported growing according to organic principles in 2015, and most of them were in developing countries [1]. The growth of certified organic land area in many developing countries was mainly driven by increasing exports of organic produce to developed nations [2-4]. Europe and North America have been by far, the main consumer markets for organic products; they have represented more than $90 \%$ of the global markets (valued at $\$ 81.6$ billion in 2015) for these goods for the last two decades [5]. With retail sales estimated at $€ 30$ billion in 2015, the European Union is the second biggest market for organic products in the world after the United States of America [1].

This article focuses on the conversion to organic FFV production in Syria where FFV provide excellent prospects for employment generation and export earnings. In 2009, Syria produced about 6 million tonnes of FFV and one-third of this production was exported [6,7]. Before the war, Syrian FFV were mainly exported to neighbouring countries and the Gulf States as well as to Eastern European 
countries. Although the EU is potentially one of the most profitable markets of high quality FFV in the world, Syrian exports of FFV to Western European countries have been small. It could be a lucrative opportunity for Syrian growers and exporters of FFV to export high-value organic products to markets such as Germany, where national production is limited to a few months due to climatic conditions. Within the EU, Germany is by far the largest market for organic products (valued at $€ 8.62$ billion in 2015) accounting for approximately $30 \%$ of the EU organic market and $12 \%$ of the aggregate international market of these products in 2015. Germany is also the largest importer of organic produce (including FFV) in Europe [1]. Yet, the organic sector in Syria is comparatively young and only a very small area of FFV is certified according to EU organic regulations. So far, no research has been conducted on Syrian farmers' attitudes towards organic FFV production. This situation calls for an investigation on the factors influencing the conversion to organic FFV production in Syria.

There has already been much research on the factors that motivate and/or hinder farmers from adopting organic agriculture. Based on empirical research, a broad range of factors have been identified as relevant in influencing farmers' decisions to adopt organic production. These factors include the socio-economic characteristics of the farmers, farm characteristics, farmers' attitudes and perceptions of risk, sources of information, national agricultural policies, governmental and non-governmental organisations (NGOs) initiatives, and membership in a farmer association. As most of this research was undertaken in developed nations, many of the elaborated factors only apply to European countries, Japan, North America, or Oceania. Foremost, subsidies and area payments dedicated to organic production were the most important factors, especially in the EU and in Switzerland [8,9]. Other important incentives in developed countries were national action plans [10], increasing institutional support for organic adoption [11], market access and consumer demand [12], development of private organic standards and labelling schemes [13], or just higher profits with organic farming practices [11,14-17]. Non-economic factors of an adoption of organic farming such as health or environmental aspects [18-20], spatial distribution of organic farming and neighbourhood influences on further adoption [21-23], cultural capital, alongside with economic capital, towards an organic conversion [24], tendencies towards the conventionalisation of organic production [25], farmer strategies and values [26], and organic farming as a lifestyle [16] were also important. Farmers' attitudes and their knowledge of organic production also contributed positively to some extent in influencing the development of organic farming [27]. In other studies, the ethics of the organic movement [28], moral and social concerns, in addition to economic factors, played a significant role in influencing farmers in their decision to adopt organic farming [18,29].

The conditions that support the adoption of organic farming among farmers in the developing world were generally dissimilar to those in developed countries. That is particularly true regarding national policy settings (especially those concerning financial support for the adoption of organic farming), farmers' financial resources, access to markets, the presence of strong domestic demand for organic products, access to extension and consulting services, as well as appropriate training facilities [30-33]. Most of the research studies on important factors for the adoption of organic farming in developing countries focused on farmers and farm characteristics as determinants of conversion to organic production (e.g., [34-41]). Other studies also included a broad range of farmers' attitudes and motives for adopting organic farming [31,42-46]. Economic aspects were specified as the most relevant factor in adopting organic farming, especially organic production dedicated to exports and emerging domestic markets [47-50]. Development projects and international aid agencies supported many farmers in developing countries as they started organic production [42,47,51]. Similarly, group certifications [38] and participatory guarantee systems-based initiatives helped many farmers in different developing countries to get certified at a relatively lower cost [52,53]. Other significant factors were farmers' access to information sources about organic farming and their ability to cultivate crops organically [35,54], farming experience and access to credits [37], access to subsidies for an organic conversion [55] as well as membership in organic associations [56]. There are many reasons mentioned in the literature as important factors for farmers: health consciousnessness of farmers [46,57-59], 
environmental benefits [60], and maintaining soil fertility and soil structure of degraded agricultural areas $[46,59,61,62]$, as well as organic agriculture as an alternative for providing food security (especially for small-scale farmers) and protecting the biodiversity from further degradation [63]. Moreover, the adoption of organic farming can be influenced positively or negatively by the social environment of farmers, the spatial distribution of organic farmers and neighbourhood effects [62].

The present study aims to increase and deepen knowledge in order to understand the factors influencing conversion to organic production among conventional farmers of FFV. To fulfill this aim, the main objective of our study is to investigate whether Syrian farmers of FFV can imagine converting their farms to organic production and the underlying reasons why they can or cannot do so. For this purpose, the attitudes and intentions of Syrian farmers of FFV towards conversion of their farms to organic farming were explored with an in-depth investigation of the factors that influence farmers' decisions to adopt organic FFV.

\section{Theoretical Model}

\subsection{Theory of Planned Behaviour}

In a socio-psychological context, intentions towards specific behaviours are considered good predictors of the actual performing of these behaviours. Many contemporary models of human social behaviour have used intentions (or similar concepts) as a critical component for understanding the behaviour in question (e.g., [64-66]). Among these models, the Theory of Planned Behaviour (TPB, [66]) is the most prominent. The scope of this theory exceeds behaviour prediction, to deal with the factors that determine the behavioural intention itself as well as the relationship between attitudes, beliefs, and behaviour. The TPB [66] is an attempt to better understand human behaviour when people may have incomplete volitional control over its implementation [67]. Thus, TPB seeks to explain human behaviour through behavioural intention based on attitudes, subjective norms, and perceived behavioural control [68]. Perceived behavioural control emphasises human ability to control the behaviour in question, which can be an important aspect in understanding farmers' decisions to adopt organic farming.

The ТРВ has gained growing attention from researchers in the agricultural field, where many studies have applied this theory as the main conceptual framework for modelling farmers' decisions to adopt new technology. The TPB has been used to understand farmers' adoption of soil conservation practices (e.g., [69]), the reduction of pesticide use and farmer safety behaviour (e.g., [70]), land management and pro-environmental agricultural practices (e.g., [71]), the adoption of agricultural best management practices (e.g., [72]), the uptake of agricultural and agroforestry innovations (e.g., [73]), the uptake of environmental conservation behaviour on the farm (e.g., [74]), climate change and water conservation strategies (e.g., [75]), as well as the adoption of an improved natural grassland management system [76]. To model the conversion to organic farming, some studies also applied the TPB model as the principal theoretical framework (Tutkun et al. in Switzerland [77]; Hattam in Mexico [78]; Kaufmann et al. in Estonia and Latvia [79]; Läpple in Ireland [80]; Sutherland in England [81]; and Asadollahpour et al. in Iran [82]).

The TPB has been proven to be an appropriate theoretical framework for modelling the conversion to organic FFV production for at least three reasons: first, conversion to organic farming necessitates careful preparation and deliberate planning by farmers; a characteristic which renders the application of the TPB as theoretical model preferable [83]. Second, the TPB accounts for social and technical factors in decision making. Third, the TPB model can take into consideration difficulties or potential constraints that farmers may perceive when adopting a new agricultural technique [84].

The TPB aims to explain why people act the way they do by trying to ascertain the determining factors of the behaviour under study. Figure 1 shows a graphical representation of the TPB, as applied in our study. The essence of the TPB is that the intention to perform (or not to perform) a specific behaviour (BI) is the immediate antecedent of that behaviour (CONV), and the intention itself is considered a 
function of attitudes towards the behaviour (ATT), subjective norms (SN) and perceived behavioural control (PBC). The TPB also stipulates that these three conceptual components of a person's intention to perform a specific behaviour are also functions of behavioural beliefs (bsoe), normative beliefs (nbmc) and control beliefs (cbpc), respectively (see Figure 1). Moreover, the abovementioned beliefs can also vary as a function of a wide range of background factors $[66,67,85]$. Against this background, the TPB can be thought of as a multidimensional model which incorporates socio-economic, socio-cultural, psychological, and economic aspects into the behaviour analysis (see Figure 1). Following the TPB, it is important to formulate questionnaire statements that represent best the TPB components. To do that, the 'principle of compatibility' was followed: "a single behaviour can be viewed as involving an action directed at a target, performed in a given context, at a certain point in time" [86] (p. 182). In our study, the four elements are explicitly identified as follows: the action is defined as 'producing FFV organically', the target is 'organic FFV, the context is 'the specific farm' and the time frame is set as 'five years'. Taking into account the principle of compatibility, all constructs within the TPB framework were measured reflectively capturing different aspects of conversion to organic FFV production.

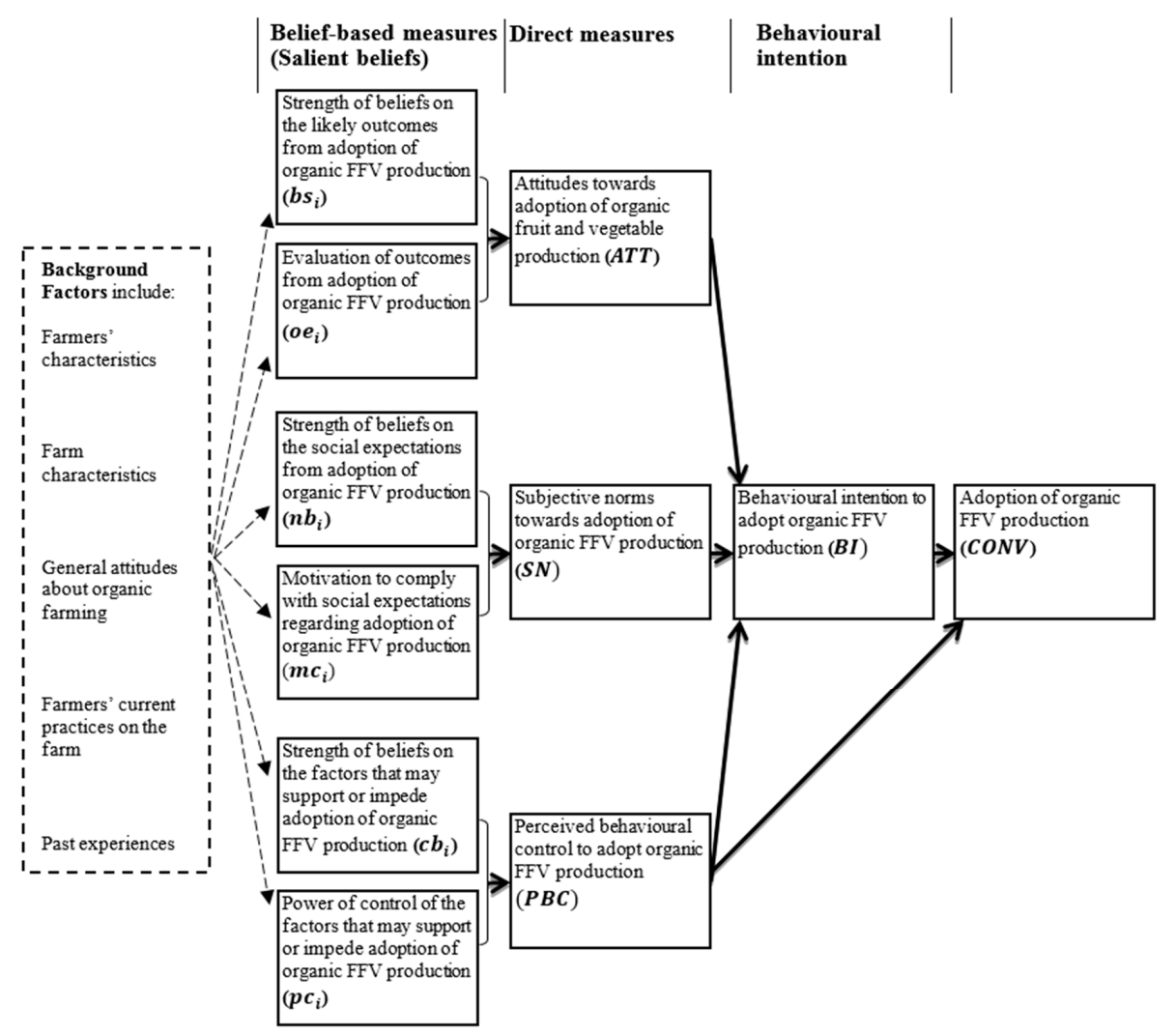

Figure 1. Model of the theory of planned behaviour for the adoption of organic fresh fruit and vegetables (FFV) by Syrian farmers within the next five years (after Fishbein and Ajzen [85]).

\subsection{Expectancy-Value Model}

The TPB follows an expectancy-value model to predict the behaviour under study $[66,86]$. The essence of this model is the expectancy or probability that performing a specific behaviour will be followed by a particular outcome and this outcome can then be evaluated by a subjective expected utility placed on this outcome [87]. According to Fishbein and Ajzen [85], the belief-based measures (calculated by the expectancy-value model) are presumably considered to provide a more accurate prediction for the behavioural intention than its direct determinants solely (attitudes, subjective norms, and perceived behavioural control), because belief-based measures can reveal why people hold certain attitudes, subjective norms, or control perceptions. 
Attitudes towards a behaviour represent an individual's favourable or unfavourable evaluation of performing a particular behaviour. A belief-based measure of the attitudes (ATT) is obtained by multiplying belief strengths $\left(b s_{i}\right)$ and outcome evaluation $\left(o e_{i}\right)$ and summing the products over the total number of accessible behavioural beliefs according to the following formula:

$$
A T T \propto \sum b s_{i} o e_{i}
$$

Strength of behavioural belief $\left(b s_{i}\right)$ is defined as the subjective probability that performing a given behaviour will produce a certain outcome $(i)$ and the outcome evaluation $\left(o e_{i}\right)$ can be regarded as the utility received if the outcome $(i)$ occurs $[66,85]$.

Subjective norms can be identified as a person's perception of the social pressure on carrying out a specific behaviour. In a manner parallel to the expectancy-value model of attitudes, subjective norms are assumed to follow this model as a function of normative beliefs which represent perceptions of respected referents' preferences about whether one should or should not perform a specific behaviour. Accordingly, subjective norms $(S N)$ are obtained by multiplying strength of normative belief $\left(n b_{i}\right)$ with motivation to comply $\left(m c_{i}\right)$ with the normative referents. The products are then summed up for all accessible referents as following:

$$
S N \propto \sum n b_{i} m c_{i}
$$

Strength of normative belief $\left(n b_{i}\right)$ is the individual's subjective probability that a specific normative referent (i) wants this individual to carry out a particular behaviour. Motivation to comply $\left(m c_{i}\right)$ represents the degree to which the individual complies with the perceived expectation of the normative referent (i) [66,85].

Perceived behavioural control deals with the factors that facilitate or impede performance of a given behaviour. A belief-based measure of perceived behavioural control $(P B C)$ is determined by weighting control belief strength $\left(c b_{i}\right)$ with power of control $\left(p c_{i}\right)$ and summing over the total number of accessible control beliefs

$$
P B C \propto \sum c b_{i} p c_{i}
$$

Strength of control belief $\left(c b_{i}\right)$ represents the subjective probability that the control factor $(i)$ is present, and power of control $\left(p c_{i}\right)$ is the degree to which factor $(i)$ facilitates or impedes performance of a particular behaviour $[66,85]$.

Behavioural intention can be briefly defined as people's motivation in the sense of their conscious plan or decision to exert effort to carry out the behaviour under consideration. Based on the belief-based measures of attitudes, subjective norms, and perceived behavioural control, the model to explain the behavioural intention $(B I)$ can be computed according to the following formula

$$
B I=\beta_{1} A T T+\beta_{2} S N+\beta_{3} P B C+\varepsilon
$$

$\beta_{1}, \beta_{2}$ and $\beta_{3}$ are empirically determined coefficients to estimate the importance of each component and $(\varepsilon)$ is an error term. This model reflects the combined influences of attitudes towards the behaviour, subjective norms, and perceived behavioural control on the behavioural intention. Thus, intention to perform the behaviour can vary according to its underlying components, which in turn vary according to the individual, the behaviour under consideration and the context in which it is performed $[66,85]$.

\section{Data Collection and Survey Design}

The data was obtained from a comprehensive survey of conventional FFV farmers in two governorates of western Syria, Lattakia and Tartous (i.e., the coastal region of Syria). This region is by far leading in the Syrian production of FFV [6] and about 100,000 farmers and workers are involved in it [88]. The farmer survey was carried out from December 2012 until mid-May 2013. Using a two-stage 
cluster random sampling procedure, 266 conventional farmers of FFV in 75 villages located in different districts of the coastal region were selected for this survey.

A total random sampling procedure would have been too difficult to employ, particularly for a population that is distributed across a wide geographic area as in the present survey. A two-stage cluster sampling procedure offers a reasonable alternative $[89,90]$. In the first stage, 75 clusters (i.e., villages) situated in different districts of the coastal region were chosen. In the second stage of the sampling procedure, several farmers in each of the clusters were randomly selected to be interviewed. The number of interviewed farmers in the chosen clusters varied between 1 and 7 , according to the size of the clusters.

Data was collected through face-to-face interviews by a project partner in Syria (Citrus Fruit Board in Tartous). Face-to-face interviews are considered the best method to approach Syrian farmers of FFV who are living in the rural areas of the coastal region, where access to mail, internet, and telephone services is not widespread. Furthermore, the novelty of the topic under study (i.e., the conversion to organic FFV production) together with the complexity of the TPB's rating scales used in this study may justify the choice of face-to-face interviews as the best feasible option for data collection. A pre-test was conducted in November 2012. Prior to the interview process, we conducted several telephone calls with the project partner (Citrus Fruit Board in Tartous and MAAR) to explain the design and the purpose of the farmer survey, its implications, the interview approach and the sample selection procedures. These frequent calls and constant communication with the project partner resulted in an agreed respondent selection process and a tentative timetable for data collection. After a pre-test was done, all ambiguous questions and statements were reformulated to make them easily comprehensible for farmers without changing their original meanings. This procedure allowed the effectiveness of the queries and statements in the questionnaire to be tested and improved before launching the data collection process. All interviews then took place either on the farm or in farmers' houses and ran without any significant problems. The interviews were conducted by trained interviewers of the Citrus Fruit Board in Tartous who read out the questions to the participating farmers and filled in the answers for them. All interviewers, who conducted the data collection, hold at least an engineer's diploma degree of engineering in agriculture and have also at least two years' work experience at the Citrus Fruit Board. To ensure the interviewers' correct proceeding in data collection, we were in regular phone contact with the director of the Citrus Fruit Board. Almost all respondents were attentive to the questionnaire and willing to spend about one hour to be interviewed.

The questionnaire was designed to capture as much information as possible from farmers. Question flow was deliberated to ensure smooth interaction between interviewers and farmers. Easy-to-answer questions were presented first in the survey, such as farmers' current practices on the farm. The second part of the survey covered the main topic for this research and involved questions and statements designed to assess the different constructs of the adopted TPB model towards a conversion to organic farming. The main focus of this survey was to explore the components of the TPB (see Figure 1), which can serve as the behaviour's cognitive foundation [85] for the application of new technology (the organic agriculture system) by Syrian farmers of FFV within the next five years. Farmers' responses on the TPB questions were measured along five-point fully anchored scales (Likert and semantic differential, Guttman and Thurstone scales). It was important that these questions were asked before the participating farmers became tired and/or the interviews ran out of time. The last part of the survey included questions that could be considered sensitive, but were easy to answer such as socio-demographic and farm characteristics (i.e., income, age, experience, education and farm size, future of the farm, etc.).

\section{Data Analysis}

To analyse the data of the farmer survey, we performed different univariate, bivariate and multivariate analysis methods by means of two statistical packages SPSS 22 and SmartPLS 3 [91]. Particular attention is given to Partial Least Squares Path Modelling (PLS-PM) (the PLS-PM is a 
variance-based technique for estimating structural equation models) which was the main analysis method for examining and estimating the parameters of the adopted TPB model in our study. PLS-PM is a prediction-oriented technique that explains the variance of dependent latent variables based on ordinary least squares (OLS). PLS-PM can be characterised by two components: the structural model and the measurement model (the PLS-PM structural model is also known as the path model or the inner model, whereas the PLS-PM measurement model is also known as the outer model) [92]. In our study, the PLS-PM structural model of the adopted TPB framework represents the path relationships among the latent constructs within the TPB model (see Figure 1). These path relationships are represented by arrows pointing from the independent latent constructs (e.g., behavioural beliefs) into the dependent latent construct (e.g., attitudes). Thus, the structural model can be perceived as regression models among independent (exogenous) and dependent (endogenous) latent constructs. Second, the PLS-PM measurement model of the TPB links the latent constructs (whether independent or dependent) with their specified observed variables (also known as items, indicators, or manifest variables). At the measurement model level, each of these latent constructs can be viewed as a component or factor derived from its observed variables [93-95].

By means of matrix algebra, the PLS-PM structural model of our TPB model can be summarised by the Equations (5) and (6) as follows:

$$
\eta_{j}=\gamma_{i j} \xi_{i}+\zeta_{j}
$$

$\xi_{i}$ is an independent latent construct (i.e., behavioural, normative, or control beliefs in our TPB model) and $\eta_{j}$ stand for a dependent latent construct (i.e., attitudes, subjective norms, or perceived behavioural control). $\gamma_{i j}$ represents the path coefficient associated with the prediction of an endogenous latent construct $\left(\eta_{j}\right)$ from an exogenous latent construct $\left(\xi_{i}\right)$. $\zeta_{j}$ is a random error term associated with prediction of a given endogenous latent construct $\left(\eta_{j}\right) . \zeta_{j}$ has an expected value (mean) of zero, and is not correlated with the exogenous latent construct $\left(\xi_{i}\right)$.

$$
\eta_{j_{\text {higher-order }}}=\beta_{j j} \eta_{j}+\gamma_{i j} \xi_{i}+\zeta_{j_{\text {higher-order }}}
$$

$\eta_{j_{h i g h e r-o r d e r}}$ is a higher-order endogenous latent construct within the TPB model (i.e., behavioural intention or the adoption decision, see Figure 1). $\beta_{j j}$ stands for the path coefficient between two endogenous latent constructs of different order (i.e., $\eta_{j}$ and $\eta_{j_{\text {higher-order }}}$ ). $\zeta_{\text {higher-order }}$ represents a random error term associated with a given higher-order endogenous latent construct $\left(\eta_{j_{\text {higher-order }}}\right) . \zeta_{j_{\text {higher-order }}}$ has an expected value (mean) of zero and is not correlated with the exogenous latent construct $\left(\xi_{i}\right)$ and with the endogenous latent construct $\left(\eta_{j}\right)$, which serve as independent constructs in the regression equation of higher-order endogenous latent constructs $\left(\eta_{j_{\text {higher-order }}}\right)$.

With respect to the measurement model of structural equation models, some authors like Bollen and Bauldry [96] and Henseler [97] distinguished between different types (formative, composite, and effect (reflective) measures), which can be used for modelling the latent constructs under investigation. Treating the constructs in our TPB model as formative or composite constructs did not yield in a better PLS-PM solution for the TPB model. Effect (reflective) indicators are the most prevalent type in social and behavioural sciences. They are chosen to correspond to the theoretical definition of the latent construct, as such they may be thought of as "manifestation" or "demonstration" of the theoretical concept. Thus, effect (reflective) indicators of a given latent construct should correlate with each other and have conceptual unity in that all indicators correspond to the same dimension of the construct [96]. Since our TPB model basically includes behavioural constructs, which are manifested by effect indicators, the best option was to treat the TPB constructs as reflective constructs, as such the latent constructs are the "causes" and their assigned indicators are the "manifestation". Accordingly, all latent constructs in our TPB model were reflectively measured, though the salient belief constructs (i.e., behavioural, normative and control beliefs) cover a wide range of information compared to the 
other constructs in our TPB model. Written in mathematical terms, the PLS-PM measurement model of our TPB model can be expressed by the following three equations:

$$
\begin{gathered}
x_{p i}=\alpha_{p}+\lambda_{p i} \xi_{i}+\varepsilon_{p i} \\
y_{g j}=\alpha_{g}+\lambda_{g j} \eta_{j}+\varepsilon_{g j} \\
y_{g j_{\text {higer-order }}}=\alpha_{g_{\text {higer-order }}}+\lambda_{g j_{\text {higer-order }}} \eta_{j_{\text {higer-order }}}+\varepsilon_{g j_{\text {higer-order }}}
\end{gathered}
$$

$x_{p i}, y_{g j}$ and $y_{g j_{\text {higer-order }}}$ represent the manifest indicators of $\xi_{\mathrm{i}}, \eta_{j}$ and $\eta_{j_{\text {higer-order }}}$, respectively. $\alpha_{p}, \alpha_{g j}$ and $\alpha_{g_{\text {higer-order }}}$ are constants. $\lambda_{p i}, \lambda_{g j}$ and $\lambda_{g j_{h i g e r-o r d e r}}$ depict the relationship between the manifest indicators $\left(x_{p i}, y_{g j}\right.$ and $\left.y_{g j_{h i g e r-o r d e r}}\right)$ and their associated reflective latent construct $\left(\xi_{\mathrm{i}}, \eta_{j}\right.$ and $\left.\eta_{j_{\text {higer-order }}}\right)$, respectively. $\varepsilon_{p i}$ and $\varepsilon_{g j}$ are the measurement errors associated with reflective manifest variables $\left(x_{p i}, y_{g j}\right.$ and $\left.y_{g j_{h i g e r-o r d e r}}\right)$ of the reflective latent construct $\left(\xi_{i}, \eta_{j}\right.$ and $\left.\eta_{j_{h i g e r-o r d e r}}\right)$. These error terms of the measurement model are assumed to be zero, and have no correlation with their associated latent constructs [94-96].

Since all TPB constructs are reflectively measured, the evaluation process of the PLS-PM measurement model includes examination of internal consistency reliability, indicator reliability, convergent validity, and discriminant validity (see Table 3). High inter-correlations among the observed measures are reflected in a high composite reliability and convergent validity of their associated construct and vice versa [92]. After evaluating the PLS-PM measurement model of the TPB for its reliability and validity, we examined the results obtained from the PLS-PM structural model. Such evaluation gives an idea of how well the TPB constructs are operationalised by the empirical data, and thus, the decision can be made whether the TPB has been practically proven. In this respect, we examined (i) the path and total effect coefficients among the latent constructs for their statistical significance and collinearity issues; and (ii) the predictive capability (i.e., $R^{2}$ values) and the predictive relevance (i.e., $Q^{2}$ values) of our TPB model (see Tables 4 and 5).

\section{Results}

\subsection{Descriptive Statistics}

To understand the key characteristics of the interviewed Syrian farmers of FFV, socio-demographic characteristics of farmers and farm attributes are presented in Table 1. This table shows that, apart from a few exceptions, the interviewed Syrian farmers were males. The age of respondents was between 23 and 88 years old, with an average age of 50 . More than $50 \%$ of the farmers were in the age group between 40 and 60 . This is feasible since most Syrian famers would only hand over their land to the second generation of the family (mainly to male children), when they were getting very old. In correspondence to farmers' age categories, farmer's experience in farming had a mean value of 28.4 years. The vast majority of respondents had a formal education, while only $8 \%$ of them reported that they had no formal education. A significant negative correlation between the age of the farmer and the level of the education $(r=-0.243$ and $p$-value $=0.000)$ was found. This reverse relationship suggests that the younger the farmers were, the better the education level they had. Interestingly, about one-third of the interviewed farmers had completed at least a university degree. The high level of education among farmers in the coastal region of Syria can be attributed to the fact that many farmers were involved in some other off-farm jobs that usually require high qualifications. Farm households were on average composed of 5.5 persons. A significant negative relationship between farm household size and the level of education $(r=-0.237$ and $p$-value $=0.000)$ was found, suggesting that farmers with higher levels of education are more likely to have smaller households compared to farmers with lower educational levels.

As Table 1 indicates, there is a large variation in farmer income from FFV production. Many farmers (and/or their family members) were involved in some other agricultural activities such as the cultivation of olives, tobacco and cereals, which were also produced in this region. Another 
reason for this variation in income can be attributed to the fact that $25 \%$ of farmers had only a small farm $(<1$ ha) and therefore they were likely to seek other work to ensure their livelihoods. Moreover, since many of the interviewed farmers possessed high qualifications, they were more likely to find other (better-paid) off-farm work (e.g., having a job at governmental institutions). This latter case may also justify the significant negative relationship that was found between farmer income from FFV cultivation and their level of education $(r=-0.229$ and $p$-value $=0.000)$.

Farm sizes varied considerably from small $(<1 \mathrm{ha})$ to relatively large farms of $25 \mathrm{ha}$. On average, interviewed farmers had farms of 2.4 ha. The area dedicated to the cultivation of FFV had a mean value of 1.6 ha. Further descriptive results of the farmer survey showed that only $10 \%$ of farmers indicated that they have received loans for FFV cultivation (mainly long-term credit at the early stages of establishing their farms). About $58 \%$ of farmers also indicated that they had received governmental subsidies for FFV cultivation over the past few years. These subsidies can be split into two types: in cash and in kind. In the former type of subsidy, farmers are provided with a specific amount of money per Donum ( $=0.1 \mathrm{ha})$ according to the kind of crops planted. In the latter type, farmers are sold certain agricultural inputs (such as seeds, fertilizers, and equipment for modern drip-irrigation) with tangible discounts compared to market prices [98]. During the current war situation in Syria, the government suspended the first type of subsidy from mid-2012 onward, while the second type was still active according to many of the interviewed farmers and MAAR experts [99]. About $85 \%$ of farmers indicated that they were working collectively with other farmers to solve farming problems, particularly those related to FFV production and marketing problems. Collective work is basically done through semi-governmental farmers' cooperatives, which are located in different towns throughout the Syrian countryside. However, many interviewed farmers mentioned that these cooperatives still suffer from poor management, marginal financial and technical resources and poor organization.

Further results showed that $60 \%$ of the farmers had heard about the term organic farming through different sources. These sources included their social environment (family, friends, and fellow farmers), organic field schools of the Syrian ministry of agriculture (MAAR), organic pioneers in the region, and media reports pertaining to organic agriculture. Farmers' knowledge of organic farming, however, varied from the basic idea of avoiding the use of chemical inputs in farming, to fully understanding what organic farming meant according to organic regulations. A significant positive correlation was found between the level of education and whether farmers had heard about the term organic farming $(r=0.294$ and $p$-value $=0.000)$. Accordingly, farmers with higher education were more likely to have a better knowledge of what exactly the term organic farming meant. Most farmers indicated that they use low chemical inputs on their farms, and that their current practices for maintaining soil fertility ( $94 \%$ of farmers) and for pest control ( $86 \%$ of farmers) includes at least one of the practices that are part of certified organic production. For instance, $89 \%$ of farmers used livestock manures on their fields and $60 \%$ and $68 \%$ of farmers indicated using biological enemies and physical-pheromone traps, respectively, for controlling pests and diseases.

Table 1. Socio-demographic characteristics of FFV farmers and farm attributes in the coastal region of Syria.

\begin{tabular}{lcc}
\hline Characteristic & Mean (Std. Deviation) & $\begin{array}{c}\text { \% of Respondents } \\
(\mathbf{N}=\mathbf{2 6 6})\end{array}$ \\
\hline Gender: & $0.98(0.12)$ & 1.5 \\
$0=$ Female & - & 98.5 \\
1 = Male & $50.47(13.49)$ & \\
\hline Age at the time of survey (years): & - & 23.3 \\
Up to 39 & - & 22.9 \\
$40-49$ & - & 27.4 \\
$50-59$ & & 26.3 \\
60 and above & & \\
\hline
\end{tabular}


Table 1. Cont.

\begin{tabular}{|c|c|c|}
\hline Characteristic & Mean (Std. Deviation) & $\begin{array}{l}\% \text { of Respondents } \\
\quad(N=266)\end{array}$ \\
\hline Experience in farming (years): & $28.42(13.90)$ & \\
\hline Up to 19 & - & 27.4 \\
\hline $20-29$ & - & 22.2 \\
\hline 30-39 & - & 20.7 \\
\hline 40 and above & - & 29.7 \\
\hline Highest education level completed: & $3.26(1.44)$ & \\
\hline 1 = Less than elementary level (No formal education) & - & 8.6 \\
\hline 2 = Elementary to less than high school & - & 33.8 \\
\hline $3=$ High school & - & 13.9 \\
\hline $4=$ Two years college (intermediate diploma) & - & 9.9 \\
\hline 5 = University or above (at least 4 years college) & - & 33.8 \\
\hline Household size (persons): $(N=251)$ & $5.45(2.31)$ & \\
\hline Up to 3 & - & 13.1 \\
\hline $4-5$ & - & 46.2 \\
\hline $6-7$ & - & 28.7 \\
\hline 8 and above & - & 12 \\
\hline $\begin{array}{l}\text { Ratio of income from FFV cultivation from total } \\
\text { household income: }\end{array}$ & $2.40(1.14)$ & \\
\hline $1=\mathrm{Up}$ to $25 \%$ & - & 28.2 \\
\hline $2=26-50 \%$ & - & 28.6 \\
\hline $3=51-75 \%$ & - & 18.4 \\
\hline $4=76-100 \%$ & - & 24.8 \\
\hline Farm size (ha): $(N=256)$ & $2.40(3.07)$ & \\
\hline Less than 1 & - & 25.4 \\
\hline 1.0-less than 2 & - & 33.2 \\
\hline 2.0-less than 4 & - & 23.8 \\
\hline 4.0 and above & - & 17.6 \\
\hline Farm size dedicated for FFV (ha): $(N=235)$ & $1.61(2.48)$ & \\
\hline Less than 0.5 & - & 20.4 \\
\hline 0.5 -less than 1 & - & 30.6 \\
\hline 1.0-less than 2 & - & 24.3 \\
\hline 2.0 and above & - & 24.7 \\
\hline Credits for FFV production (long term credits): & $0.10(0.30)$ & \\
\hline $1=$ Yes & - & 10.2 \\
\hline $0=\mathrm{No}$ & - & 89.8 \\
\hline Access to governmental subsidies for FFV production: & $0.58(0.50)$ & \\
\hline $1=$ Yes & - & 57.9 \\
\hline $0=\mathrm{No}$ & - & 42.1 \\
\hline $\begin{array}{l}\text { Working collectively with other farmers to solve } \\
\text { farming problems (e.g., production and marketing } \\
\text { problems): }\end{array}$ & $0.85(0.35)$ & \\
\hline $1=$ Yes & - & 85.3 \\
\hline $0=\mathrm{No}$ & - & 14.7 \\
\hline
\end{tabular}

Most farmers had positive attitudes towards aspects of organic farming. These attitudes were measured on a five-point Likert scale from $1=$ strongly disagree to $5=$ strongly agree. Farmers rated many statements positively regarding the environmental, health and economic aspects of organic agriculture. For instance, all interviewed farmers were concerned about providing healthy food to their families and they perceived organic products as healthier than conventional ones (mean-score of 4.86); $94 \%$ of them perceived that using chemical inputs in agriculture has negative impacts on the health of both people and animals (mean-score of 4.63); and $98 \%$ of farmers also indicated that organic farming can play a significant role in mitigating environmental problems through the reduction of chemical outputs into nature (mean-score of 4.70). Attitudes towards economic and profitability aspects of organic farming were also positively rated, however with smaller mean-scores and higher standard deviations than those related to environmental and health consciousness. Thus, $60 \%$ of 
farmers agreed that organic products can be sold for higher prices compared to conventional products (mean-score of 3.63 ) and $57 \%$ of them also perceived organic farming as more profitable than its conventional counterpart (mean-score of 3.47). About $59 \%$ of farmers indicated that yields in organic farming are not low and that they can be equivalent to the yields of conventional farming. Also, $60 \%$ of farmers stated that conversion to organic farming may require high investment costs. This is comprehensible, as many farmers perceived that some of the required inputs for organic farming (particularly organic seeds and organic pesticides) might be either expensive or even unavailable on the local market. The availability of organic certification bodies and the costs of inspection and certification are also important factors that may hinder or discourage farmers from converting to organic farming. In this context, most interviewed farmers stated that certification bodies for organic farming were not available in their region. Only about $18 \%$ of the farmers perceived the costs of inspection and certification in organic farming as relatively low. In contrast, $30 \%$ of farmers deemed those costs unaffordable. The lack of the organic farming certification and inspection bodies in the research sites might be a reason why many farmers were not well-informed about inspection costs and certification services.

Market availability for organic products is also an essential factor that motivates or impedes farmers from converting their farms to organic agriculture. Although about $57 \%$ of farmers were convinced that local consumers would be willing to pay a price premium for organic products, only $15 \%$ of farmers perceived that local markets for organic products were available to some extent in the two largest metropolitan cities in Syria (Aleppo and Damascus). More than $60 \%$ of farmers in this survey also agreed with the statement that it is hard to find commercial buyers (wholesalers, processors, or exporters) who are willing to pay higher prices for organic products. Most farmers indicated that it is not difficult to obtain information and consulting regarding organic farming. However, two-thirds of farmers perceived that obtaining information about and/or having access to export markets of organic products is relatively difficult. The lack of information about the organic market potential (either in the local or export markets) may explain to some extent the relative negative rating of the statements related to the market prospects of organic products. Though MAAR was successful in encouraging organic farming in some crops such as cotton and olives (which are export-market oriented), about $80 \%$ of FFV farmers in this survey indicated that MAAR programmes are still not sufficient for promoting organic farming among FFV farmers.

\subsection{PLS-PM Results of the TPB}

\subsubsection{Assessing the PLS-PM Measurement Model}

The first examination of the internal consistency of the TPB constructs was performed by means of Cronbach's alpha, followed by assessing the PLS-PM measurement model of the TPB by means of reliability and convergent validity tests (see Tables 2 and 3). Table 2 shows Cronbach's alpha for the TPB constructs. Most of the TPB constructs achieved acceptable levels of Cronbach's alpha (above 0.70), Cronbach's alpha of 0.64 for normative beliefs and of 0.62 for subjective norms are also acceptable since the current study was exploratory research [92].

Table 2. Cronbach's alpha results for the Theory of Planned Behaviour (TPB) survey among FFV farmers in the coastal region of Syria.

\begin{tabular}{clcc}
\hline $\begin{array}{c}\text { Latent } \\
\text { Construct }\end{array}$ & \multicolumn{1}{c}{ Definition } & $\begin{array}{c}\text { Observed } \\
\text { Measures }\end{array}$ & $\begin{array}{c}\text { Cronbach's } \\
\text { Alpha }\end{array}$ \\
\hline CONV & $\begin{array}{l}\text { Adoption of organic FFV production on the farm within } \\
\text { the next five years. }\end{array}$ & 2 & 0.806 \\
\hline BI & $\begin{array}{l}\text { Behavioural intention to adopt organic FFV production on } \\
\text { the farm within the next five years. }\end{array}$ & 2 & 0.805 \\
\hline
\end{tabular}


Table 2. Cont.

\begin{tabular}{clcc}
\hline $\begin{array}{c}\text { Latent } \\
\text { Construct }\end{array}$ & \multicolumn{1}{c}{ Definition } & $\begin{array}{c}\text { Observed } \\
\text { Measures }\end{array}$ & $\begin{array}{c}\text { Cronbach's } \\
\text { Alpha }\end{array}$ \\
\hline ATT & $\begin{array}{l}\text { Attitudes towards the adoption of organic FFV production } \\
\text { on the farm within the next five years. }\end{array}$ & 4 & 0.790 \\
\hline PBC & $\begin{array}{l}\text { Perceived behavioural control to adopt organic production } \\
\text { on the farm within the next five years. }\end{array}$ & 6 & 0.795 \\
\hline SN & $\begin{array}{l}\text { Subjective norms towards the adoption of organic FFV } \\
\text { production on the farm within the next five years. }\end{array}$ & 3 & 0.622 \\
\hline bsoe & $\begin{array}{l}\text { Behavioural beliefs regarding adoption of organic FFV } \\
\text { production on the farm within the next five years. }\end{array}$ & $9 \times 2$ & 0.750 \\
\hline cbpc & $\begin{array}{l}\text { Control beliefs on the factors that may support or impede } \\
\text { adoption of organic FFV production on the farm within } \\
\text { the next five years. }\end{array}$ & $8 \times 2$ & 0.722 \\
\hline nbmc & $\begin{array}{l}\text { Normative beliefs regarding adoption of organic FFV } \\
\text { production on the farm within the next five years. }\end{array}$ & $7 \times 2$ & 0.640 \\
\hline
\end{tabular}

Note: The set of salient beliefs (bsoe, cbpc and nbmc) are calculated through the expectancy-value model. $N=266$. Source: Own data.

Table 3 exhibits the results of the PLS-PM measurement model of our TPB model. Running a consistent partial least squares (PLSc) $[100,101]$ instead of the traditional PLS-PM lead to a misspecification of the model. Therefore, our results are based on the traditional PLS-PM solution. In Table 3, the measurements of reliability and convergent validity of the PLS-PM measurement model are provided. Indicator loadings, the fifth column in Table 3, show that most indicators of the TPB model were highly loading on their specified constructs, suggesting that these indicators were reliable measures of the constructs under investigation. Highly reliable indicators were also reflected in high internal reliability on the construct level as can be seen by the high composite reliability values above 0.70 in Table 3. With respect to convergent validity of the TPB model, the endogenous latent constructs (CONV, BI, ATT, PBC, and SN) demonstrated strong convergent validities, where the average variance extracted (AVE) values were above 0.50 (see Table 3). The set of salient beliefs (bsoe, cbpc and nbmc) exhibited values of AVE lower than 0.50, though they had high composite reliabilities. The low AVE values of the belief constructs can be justified, as those constructs are multidimensional and comprise a wide range of information about the behaviour under consideration. These low AVE values can also be confirmed by the relatively low indicator loadings in the case of belief constructs with comparison to the indicator loadings of the endogenous constructs.

Table 3. Reliability and convergent validity tests of the TPB model of farmers in the coastal region of Syria to adopt organic FFV production within the next five years.

\begin{tabular}{|c|c|c|c|c|c|c|c|c|c|}
\hline \multirow{2}{*}{$\begin{array}{c}\text { Latent } \\
\text { Constructs }\end{array}$} & \multirow{2}{*}{ Mean } & \multirow{2}{*}{ SD } & \multicolumn{4}{|c|}{ Observed Indicators } & \multirow{2}{*}{$\operatorname{AVE}^{(1)}$} & \multirow{2}{*}{$\begin{array}{c}\text { Composite } \\
\text { Reliability }\end{array}$} & \multirow{2}{*}{$\begin{array}{l}\text { Convergent } \\
\text { Validity? }\end{array}$} \\
\hline & & & Code & Loadings & Weights & VIF & & & \\
\hline \multirow{4}{*}{$\begin{array}{l}\text { Attitudes } \\
\text { (ATT) }\end{array}$} & \multirow{4}{*}{4.03} & \multirow{4}{*}{0.70} & Att_1 & 0.784 & 0.298 & 1.713 & \multirow{4}{*}{0.615} & \multirow{4}{*}{0.864} & \multirow{4}{*}{ Yes } \\
\hline & & & Att_2 & 0.850 & 0.360 & 1.967 & & & \\
\hline & & & Att_3 & 0.778 & 0.324 & 1.554 & & & \\
\hline & & & Att_4T & 0.719 & 0.289 & 1.388 & & & \\
\hline \multirow{2}{*}{$\begin{array}{l}\text { Behavioural } \\
\text { intention (BI) }\end{array}$} & \multirow{2}{*}{4.13} & \multirow{2}{*}{0.75} & bi_1T & 0.913 & 0.541 & 1.833 & \multirow{2}{*}{0.837} & \multirow{2}{*}{0.911} & \multirow{2}{*}{ Yes } \\
\hline & & & bi_2 & 0.917 & 0.552 & 1.833 & & & \\
\hline \multirow{2}{*}{$\begin{array}{l}\text { Conversion } \\
\text { (CONV) }\end{array}$} & \multirow{2}{*}{4.01} & \multirow{2}{*}{0.75} & conv_1 & 0.910 & 0.532 & 1.836 & \multirow{2}{*}{0.838} & \multirow{2}{*}{0.912} & \multirow{2}{*}{ Yes } \\
\hline & & & conv_2T & 0.920 & 0.560 & 1.836 & & & \\
\hline
\end{tabular}


Table 3. Cont.

\begin{tabular}{|c|c|c|c|c|c|c|c|c|c|}
\hline \multirow{2}{*}{$\begin{array}{c}\text { Latent } \\
\text { Constructs }\end{array}$} & \multirow{2}{*}{ Mean } & \multirow{2}{*}{ SD } & \multicolumn{4}{|c|}{ Observed Indicators } & \multirow{2}{*}{$\operatorname{AVE}^{(1)}$} & \multirow{2}{*}{$\begin{array}{c}\text { Composite } \\
\text { Reliability }\end{array}$} & \multirow{2}{*}{$\begin{array}{c}\text { Convergent } \\
\text { Validity? }\end{array}$} \\
\hline & & & Code & Loadings & Weights & VIF & & & \\
\hline \multirow{6}{*}{$\begin{array}{c}\text { Perceived } \\
\text { behavioural } \\
\text { control (PBC) }\end{array}$} & \multirow{6}{*}{4.05} & \multirow{6}{*}{0.61} & Pbc_1 & 0.783 & 0.223 & 2.181 & \multirow{6}{*}{0.509} & \multirow{6}{*}{0.856} & \multirow{6}{*}{ Yes } \\
\hline & & & Pbc_2 & 0.850 & 0.275 & 2.663 & & & \\
\hline & & & Pbc_3 & 0.791 & 0.261 & 1.817 & & & \\
\hline & & & Pbc_4 4 & 0.391 & 0.116 & 1.120 & & & \\
\hline & & & Pbc_5 & 0.710 & 0.237 & 1.478 & & & \\
\hline & & & info_3 & 0.660 & 0.260 & 1.291 & & & \\
\hline \multirow{3}{*}{$\begin{array}{l}\text { Subjective } \\
\text { norms (SN) }\end{array}$} & \multirow{3}{*}{3.78} & \multirow{3}{*}{0.75} & sn_1 & 0.760 & 0.562 & 1.093 & \multirow{3}{*}{0.506} & \multirow{3}{*}{0.754} & \multirow{3}{*}{ Yes } \\
\hline & & & sn_2 & 0.682 & 0.404 & 1.157 & & & \\
\hline & & & sn_3T & 0.690 & 0.431 & 1.147 & & & \\
\hline \multirow{9}{*}{$\begin{array}{c}\text { Behavioural } \\
\text { beliefs (bsoe) }\end{array}$} & \multirow{9}{*}{20.55} & \multirow{9}{*}{2.70} & bsoe_1 & 0.551 & 0.162 & 1.288 & \multirow{9}{*}{0.356} & \multirow{9}{*}{0.820} & \multirow{9}{*}{-} \\
\hline & & & bsoe_2 & 0.720 & 0.201 & 1.910 & & & \\
\hline & & & bsoe_3 & 0.740 & 0.254 & 1.886 & & & \\
\hline & & & bsoe_4 & 0.654 & 0.176 & 1.517 & & & \\
\hline & & & bsToe_5 & 0.208 & $0.068 *$ & 1.076 & & & \\
\hline & & & bsoe_6 & 0.554 & 0.175 & 1.288 & & & \\
\hline & & & bsoe_7 & 0.725 & 0.238 & 1.701 & & & \\
\hline & & & bsoe_8 & 0.651 & 0.206 & 1.533 & & & \\
\hline & & & bsToe_9 & 0.332 & 0.135 & 1.063 & & & \\
\hline \multirow{8}{*}{$\begin{array}{c}\text { Control } \\
\text { beliefs (cbpc) }\end{array}$} & \multirow{8}{*}{16.99} & & cbpc_1 & 0.694 & 0.246 & 1.483 & & & \\
\hline & & & cbpc_2 & 0.728 & 0.255 & 1.552 & & & \\
\hline & & & cbpc_3 & 0.588 & 0.196 & 1.481 & & & \\
\hline & & & cbpc_4 & 0.739 & 0.283 & 1.478 & 0.357 & 0.800 & - \\
\hline & & 4.14 & cbpc_5 & 0.495 & 0.155 & 1.278 & $(0.403)$ & $(0.822)$ & - \\
\hline & & & cbpc_6 & 0.152 & 0.022 & 1.065 & & & \\
\hline & & & cbpc_7 & 0.487 & 0.150 & 1.244 & & & \\
\hline & & & cbpc_8 & 0.661 & 0.253 & 1.318 & & & \\
\hline & & & nbmc_1 & 0.577 & 0.310 & 1.215 & & & \\
\hline & & & nbmc_2 & 0.660 & 0.325 & 1.322 & & & \\
\hline & & & nbmc_3 & 0.688 & 0.363 & 1.474 & & & \\
\hline Normative & 13.87 & 4.15 & nbmc_4 & $0.375^{* *}$ & 0.005 & 1.366 & 0.300 & $\begin{array}{l}0.740 \\
\end{array}$ & - \\
\hline beliefs (nbmc) & & & nbmc_5 & 0.533 & 0.261 & 1.394 & $(0.343)$ & $(0.753)$ & \\
\hline & & & nbmc_6 & 0.573 & 0.287 & 1.311 & & & \\
\hline & & & nbmc_7 & $0.327^{* *}$ & 0.159 & 1.064 & & & \\
\hline
\end{tabular}

Note: $N=266$. Bold indicator loadings and/or weights are significant at $p<0.001 ;{ }^{*}$ indicator loading and/or weights are significant at $p=0.05$ and ${ }^{* *}$ indicator loading and/or weights are significant at $p=0.01$. VIF: Variance inflation factor and AVE: Average variance extracted. ${ }^{(1)}$ The values in brackets represent the AVE after disregarding cbpc_6, and nbmc_7 from the model. ${ }^{(2)}$ The values in brackets represent the composite reliability after disregarding cbpc_6, and nbmc_7 from the model. The original data of endogenous constructs ranges from 1 to 5 and for the exogenous constructs from 1 to 25 . All input and output data of PLS-PM are standardised. Source: Own data.

A cross-loading test of the TPB model showed that all constructs had established discriminant and convergent validities, since the indicators of each construct were loading higher on their specified constructs than they loaded on the other constructs in the TPB model. Few of these indicators had relatively high cross-loadings on other constructs of the TPB model, though they were lower than their loadings on the associated constructs. Alike cross-loading test, Fornell-Larcker criterion indicated that all constructs of our TPB are empirically distinctive from each other.

Though cross-loading test and Fornell-Larcker criterion are the most popular in social sciences for estimating discriminant validity, they have been criticised over the past two years. For instance, Henseler et al. [102] considered them insufficient and called for a new criterion for assessing discriminant validity in variance-based structural equation modelling. As an alternative, Henseler and his colleagues suggested Heterotrait-Monotrait Ratio (HTMT) as the best criterion for discriminant validity [102]. The result of HTMT are presented in Table 4 . The results show that the discriminant validity of the model has been established, since the HTMT values are significantly lower than 1 . Most of HTMT values fulfilled the most conservative threshold (HTMT ${ }_{0.85}$ ), since their values are lower than 0.85 . The HTMT value of attitude and behavioural intention (0.876) indicates a discriminant validity at HTMT 0.90 . Two HTMT values exceeds HTMT 0.90 threshold: the constructs of attitudes and perceived behavioural control $(\mathrm{HTMT}=0.918)$ and the constructs of behavioural intention and 
conversion $(\mathrm{HTMT}=0.935)$. Nevertheless, $\mathrm{HTMT}_{\text {inference, }}$, the most liberal HTMT threshold, shows that the construct validities of these construct are also established.

Table 4. Discriminant validity test of the TPB model of farmers in the coastal region of Syria to adopt organic FFV production within the next five years: Heterotrait-Monotrait Ratio (HTMT).

\begin{tabular}{|c|c|c|c|c|c|c|c|c|}
\hline Latent Constructs & ATT & BI & CONV & PBC & SN & bsoe & cbpc & nbmc \\
\hline Attitudes (ATT) & & & & & & & & \\
\hline Behavioural intention (BI) & 0.876 & & & & & & & \\
\hline Conversion (CONV) & 0.825 & 0.935 & & & & & & \\
\hline Perceived behavioural control (PBC) & 0.918 & 0.771 & 0.785 & & & & & \\
\hline Subjective Norms (SN) & 0.843 & 0.685 & 0.609 & 0.663 & & & & \\
\hline Behavioural beliefs (bsoe) & 0.808 & 0.654 & 0.645 & 0.691 & 0.776 & & & \\
\hline Control beliefs (cbpc) & 0.791 & 0.659 & 0.700 & 0.759 & 0.729 & 0.850 & & \\
\hline Normative beliefs (nbmc) & 0.452 & 0.333 & 0.319 & 0.523 & 0.586 & 0.557 & 0.568 & \\
\hline
\end{tabular}

\subsubsection{Path and Total Effect Coefficients of PLS-PM Structural Model}

The results of PLS-PM of our TPB model showed that farmers' positive attitudes and perceived behavioural control towards the conversion to organic FFV production had a positive influence on the behavioural intention to convert. These findings are in line with the TPB assumptions. Subjective norms towards a conversion to organic FFV production, however, played a small role in forming behavioural intention in our study. Furthermore, the direct components of behavioural intention (ATT, PBC and SN) were also well predicted by their respective salient beliefs (bsoe, cbpc and nbmc). Moving on in the TPB model, the behavioural intention was found as the primary predictor of the decision to adopt organic FFV production, followed by the perceived behavioural control towards this behaviour. PLS path modelling results in Table 5 confirm that the paths linking the TPB components had significant coefficients at $p<.05$ (with one exception for the path from $\mathrm{SN}$ to BI, which was found not significant). Table 5 also includes the total effect coefficients that demonstrate the chain of causal effects from the set of salient beliefs (bsoe, cbpc, nbmc) to the behaviour (CONV) in the TPB model. Results further indicate that most of the total effect coefficients were highly significant at $p<0.001$. Though normative beliefs had a significant effect on subjective norms, their total effects on behavioural intention and behaviour was not significant.

Table 5. Path and total effect coefficients of TPB constructs on behavioural intention to adopt organic FFV production $(\mathrm{BI})$ and adoption decision $(\mathrm{CONV})$ by farmers in the coastal region of Syria within the next five years.

\begin{tabular}{|c|c|c|c|c|}
\hline $\begin{array}{c}\rightarrow \text { : Effect Direction (e.g., Attitudes } \\
\rightarrow \text { Behaviour: Represents } \\
\text { Effects of Attitudes on Behaviour) }\end{array}$ & $\begin{array}{c}\text { Coefficients } \\
\text { (Original Sample) } \\
(N=266)\end{array}$ & $\begin{array}{c}\text { Coefficients } \\
\text { (Sample Mean }^{(1)} \text { ) }\end{array}$ & $\begin{array}{l}\text { Standard Error } \\
\qquad(N=266)\end{array}$ & $p$-Value \\
\hline $\begin{array}{l}\text { Attitudes (ATT) } \rightarrow \\
\text { Behaviour (CONV) }\end{array}$ & $0.317^{* *}$ & 0.315 & 0.070 & 0.000 \\
\hline $\begin{array}{l}\text { Attitudes (ATT) } \rightarrow \\
\text { Behavioural intention (BI) }\end{array}$ & $0.482 * *$ & 0.477 & 0.089 & 0.000 \\
\hline $\begin{array}{c}\text { Behavioural intention }(\mathrm{BI}) \rightarrow \\
\text { Behaviour (CONV) }\end{array}$ & $0.658^{* *}$ & 0.657 & 0.055 & 0.000 \\
\hline $\begin{array}{c}\text { Perceived behavioural control (PBC) } \rightarrow \\
\text { Behaviour }(\text { CONV) }\end{array}$ & $\begin{array}{c}0.368^{* *} \\
\left(0.216^{* *}\right)^{(2)}\end{array}$ & 0.371 & 0.066 & 0.000 \\
\hline $\begin{array}{c}\text { Perceived behavioural control (PBC) } \rightarrow \\
\text { Behavioural intention }(\mathrm{BI})\end{array}$ & 0.232 * & 0.236 & 0.076 & 0.002 \\
\hline $\begin{array}{c}\text { Subjective norm (SN) } \rightarrow \\
\text { Behaviour (CONV) }\end{array}$ & 0.058 & 0.059 & 0.040 & 0.143 \\
\hline $\begin{array}{c}\text { Subjective norm }(\mathrm{SN}) \rightarrow \text { Behavioural } \\
\text { intention }(\mathrm{BI})\end{array}$ & 0.088 & 0.091 & 0.066 & 0.144 \\
\hline
\end{tabular}


Table 5. Cont.

\begin{tabular}{|c|c|c|c|c|}
\hline $\begin{array}{l}\rightarrow \text { : Effect Direction (e.g., Attitudes } \\
\rightarrow \text { Behaviour: Represents } \\
\text { Effects of Attitudes on Behaviour) }\end{array}$ & $\begin{array}{l}\text { Coefficients } \\
\text { (Original Sample) } \\
(N=266)\end{array}$ & $\begin{array}{c}\text { Coefficients } \\
\text { (Sample Mean }{ }^{(1)} \text { ) }\end{array}$ & $\begin{array}{l}\text { Standard Error } \\
\quad(N=266)\end{array}$ & $p$-Value \\
\hline $\begin{array}{l}\text { Behavioural beliefs (bsoe) } \\
\rightarrow \text { Behaviour (CONV) }\end{array}$ & 0.200 ** & 0.202 & 0.050 & 0.000 \\
\hline $\begin{array}{l}\text { Behavioural beliefs (bsoe) } \rightarrow \\
\text { Behavioural intention (BI) }\end{array}$ & $0.304^{* *}$ & 0.306 & 0.066 & 0.000 \\
\hline $\begin{array}{c}\text { Behavioural beliefs (bsoe) } \rightarrow \\
\text { Attitudes (ATT) }\end{array}$ & 0.629 ** & 0.639 & 0.037 & 0.000 \\
\hline $\begin{array}{l}\text { Control beliefs (cbpc) } \rightarrow \\
\text { Behaviour (CONV) }\end{array}$ & $0.224^{* *}$ & 0.229 & 0.046 & 0.000 \\
\hline $\begin{array}{c}\text { Control beliefs (cbpc) } \rightarrow \text { Behavioural } \\
\text { intention (BI) }\end{array}$ & 0.141 * & 0.145 & 0.048 & 0.003 \\
\hline $\begin{array}{l}\text { Control beliefs (cbpc) } \rightarrow \text { Perceived } \\
\text { behavioural control (PBC) }\end{array}$ & $0.608^{* *}$ & 0.616 & 0.043 & 0.000 \\
\hline $\begin{array}{c}\text { Normative beliefs (nbmc) } \rightarrow \\
\text { Behaviour (CONV) }\end{array}$ & 0.021 & 0.023 & 0.016 & 0.180 \\
\hline $\begin{array}{l}\text { Normative beliefs (nbmc) } \rightarrow \\
\text { Behavioural intention (BI) }\end{array}$ & 0.032 & 0.035 & 0.024 & 0.183 \\
\hline $\begin{array}{l}\text { Normative beliefs }(\mathrm{nbmc}) \rightarrow \\
\quad \text { Subjective norm }(\mathrm{SN})\end{array}$ & $0.368^{* *}$ & 0.390 & 0.052 & 0.000 \\
\hline
\end{tabular}

Total effects $=$ direct effects (i.e., path coefficient when there is a direct path connecting two given components of TPB model) + indirect effects (i.e., mediated effects) between two components, not necessarily, having direct path connecting them). *: Total effect coefficient of original sample $(N=266)$ is significant at $p<0.01$ and **: coefficient is significant at $p<0.001$. (1): Sample mean represents the total effect mean obtained from PLS bootstrapping procedure (5000 samples of 266 cases for each). ${ }^{(2)}$ : a coefficient of $0.216^{* *}$ represents the direct effect of PBC on CONV. Source: Own data.

\subsubsection{Predictive Accuracy and Predictive Relevance of PLS-PM Structural Model}

Table 6 exhibits the results of TPB model predictive accuracy and relevance. $R^{2}$ values of the TPB endogenous constructs vary from a small value of 0.14 in the case of subjective norms to a substantial value of 0.66 in the case of the decision to adopt organic FFV production. However, all values were found to be much greater than the minimum $R^{2}$ values required in a quantitative research [92], and thus, indicating that the TPB model had a good predictive accuracy. The effect size of a given predictor construct $\left(f^{2}\right)$ on the predictive accuracy of a predicted construct within the TPB model can be calculated from the changes in $R^{2}$ values whether a given predictor construct is included in or excluded from the OLS path model of the predicted construct. The effect sizes of ATT, PBC and SN on the predictive accuracy of BI and CONV are provided in Table 6. Attitudes apparently had the most important effect on behavioural intention, followed by perceived behavioural control, and subjective norms. With respect to the effect sizes of predictor constructs on the behaviour under consideration, behavioural intention had the largest effect on behaviour, followed by perceived behavioural control. Attitudes and subjective norms, however, had only very small effects on the behaviour.

For assessing the predictive relevance $\left(Q^{2}\right.$ values) of the PLS-PM structural model, the blindfolding procedure was utilised. The results in Table 6 show that the PLS-PM structural model had predictive relevance for all TPB endogenous constructs, where all $Q^{2}$ values were found to be greater than 0 . In terms of $Q^{2}$ values, subjective norms had the lowest predictive relevance within the TPB model, while the behavioural intention and behaviour were the constructs with the highest predictive relevance. Table 6 indicates that the result patterns of the effect sizes of construct's predictive relevance $\left(q^{2}\right)$ on the behavioural intention and behaviour were similar to the effect sizes of predictive accuracy. Though PBC's effect size of predictive relevance on the behaviour was large, its effect size on predictive accuracy was rather small to medium. This suggests the relative importance of PBC in predicting the behaviour under investigation. 
Table 6. Predictive accuracy and predictive relevance of the TPB model of FFV farmers in the coastal region of Syria.

\begin{tabular}{|c|c|c|c|c|c|c|c|c|c|c|}
\hline \multirow[b]{3}{*}{ CONV } & \multicolumn{5}{|c|}{ Model Predictive Accuracy } & \multicolumn{5}{|c|}{ Model Predictive Relevance } \\
\hline & \multirow{2}{*}{$\begin{array}{c}R^{2} \\
0.659\end{array}$} & \multicolumn{2}{|c|}{$\begin{array}{c}\text { Effect Size on } \\
\text { Behavioural } \\
\text { Intention }\left(f^{2}\right)\end{array}$} & \multicolumn{2}{|c|}{$\begin{array}{l}\text { Effect Size on } \\
\text { Behavior }\left(f^{2}\right)\end{array}$} & \multirow{2}{*}{$\begin{array}{c}Q^{2} \\
0.502\end{array}$} & \multicolumn{2}{|c|}{$\begin{array}{l}\text { Effect Size of } \\
\text { Construct's } \\
\text { Predictive } \\
\text { Relevance on } \\
\text { Behavioural } \\
\text { Intention }\left(q^{2}\right)\end{array}$} & \multicolumn{2}{|c|}{$\begin{array}{c}\text { Effect Size of } \\
\text { Construct's } \\
\text { Predictive } \\
\text { Relevance on } \\
\text { Behaviour }\left(q^{2}\right)\end{array}$} \\
\hline & & - & - & - & - & & - & - & - & - \\
\hline BI & 0.526 & - & - & 0.758 & very large & 0.401 & - & - & 0.471 & very large \\
\hline ATT & 0.396 & 0.212 & $\begin{array}{l}\text { between } \\
\text { medium } \\
\text { and large }\end{array}$ & 0.000 & very small & 0.214 & 0.141 & medium & 0.216 & $\begin{array}{l}\text { between } \\
\text { medium } \\
\text { and large }\end{array}$ \\
\hline РBC & 0.369 & 0.050 & $\begin{array}{l}\text { between } \\
\text { small and } \\
\text { medium }\end{array}$ & 0.079 & $\begin{array}{l}\text { between } \\
\text { small and } \\
\text { medium }\end{array}$ & 0.160 & 0.032 & $\begin{array}{l}\text { between } \\
\text { small and } \\
\text { medium }\end{array}$ & 0.390 & large \\
\hline SN & 0.135 & 0.006 & very small & 0.000 & very small & 0.058 & 0.009 & very small & 0.005 & very small \\
\hline
\end{tabular}

Note. $N=266$. The predictive accuracy of the TPB endogenous constructs is calculated by means of PLS-PM algorithm, while the predictive relevance of those constructs is obtained by blindfolding procedure of PLS-PM (the blindfolding procedure was calculated based on omitted distance: $\mathrm{D}=5$ ). All input and output data of PLS-PM are standardised. $Q^{2}>0$ : Endogenous construct has predictive relevance. $f^{2}$ and $q^{2}$ values of $0.02,0.15$ and 0.35 , respectively, represent small, medium, and large effects on the prediction of BI and CONV. Source: own data.

\section{Discussion and Conclusions}

With respect to the theoretical and methodological approach of the present study, few studies so far have investigated the conversion to organic farming upon either partial or full implementation of the TPB as theoretical framework (e.g., [78,80,82,103]). However, unlike our study, none of these studies used the PLS-PM approach as the main tool to analyse and examine the causal relationships throughout the theoretical model. Though subjective norms in our study played a minor role in forming the behavioural intention, our TPB model showed its aptitude and importance as an appropriate theoretical framework for modelling and understanding the decision-making process of Syrian farmers regarding the adoption of organic FFV. By boosting and augmenting the economic model of organic farming with a socio-psychology model of behaviour and ideas from rural sociology as was presented in the adopted TPB model, our study makes a substantial contribution to the literature regarding a new technology adoption in developing countries. Thus, the different constructs of the TPB were able to capture and combine a wide range of information needed for decision-making in one single model. Accordingly, the adopted model included farmers' beliefs, perceptions, subjective norms, and attitudes about different aspects of organic farming (i.e., economic, environmental, health, and animal welfare) to predict farmers' intentions and the likelihood of converting their farms to organic FFV within the next five years. Obtained results of PLS-PM confirm the stipulated relationships within the theory and provide further evidence of the profound role of the TPB model used in this study. In comparison to our findings, Hattam [78] found that Mexican farmers had generally positive attitudes towards organic avocado production; however, their intentions to adopt organic farming were rather weak, suggesting that favourable attitudes alone are not sufficient to explain the behavioural intention. Moreover, the influence of perceived social pressure and perceived ease of conversion were found to be influential on farmers' intentions to adopt organic avocado production [78]. In accordance with our findings, Asadollahpour et al. [82] found the TPB model to be a largely relevant and constituent model for predicting the conversion to organic farming among rice farmers in Iran. Interestingly, unlike our study, Asadollahpour and his colleagues found perceived behavioural control to have a stronger effect on the conversion decision than the behavioural intention had [82]. In line with our study, Terano et al. [103] found that perceived behavioural control and attitudes were the main drivers of the behavioural intention among Malaysian farmers, while subjective norms were found not significant. 
The level of farmers' awareness and knowledge about sustainable farming practices were also found to have direct effects on the behavioural intention [103].

With respect to farm and farmer characteristics, the results of our study show that a strong intention to convert to organic agriculture can be seen particularly among farmers who were already using many organic practices and low chemical inputs. Furthermore, the intention to adopt FFV production was particularly strong with Syrian farmers who had a better educational level and a better income obtained from FFV cultivation. Interestingly, most interviewed farmers of FFV in the present research had obtained at least a high school degree. In contrast to this finding, many studies from developing countries showed farmers as having a lower educational level such as Hattam in Mexico [78], Sarker et al. in Bangladesh [42], Pornpratansombat et al. in Thailand [43], and Karki et al. in Nepal [31]. Furthermore, farmer's age and experience in cultivation of FFV played only a small role in the decision to adopt organic FFV production within the next five years. Interestingly, Sarker and Itohara [57] and Karki et al. [31] found that older, more experienced farmers can better cope with organic farming practices than younger farmers who usually have less farming experience. These two studies further indicated that farmers with larger land holdings (i.e., a sign of farmers' wealth in Bangladesh and Nepal) have a greater ability to convert their farms to organic [31,57]. The land holding size in Syria is also an important indicator of a farmer's wealth. However, in the present research, the farm size did not show a direct influence on farmers' intentions to convert to organic FFV production within the next five years. Nevertheless, the farm size and other farm and farmer characteristics (such as the educational levels of farmers and their income from FFV cultivation, farmers' current practices on their farms and their general attitudes about organic farming) were found to have indirect effects on the behavioural intention to adopt organic FFV production (see Figure 1). In accordance with the TPB assumptions, these variables served as background factors that had direct influences on the set of accessible beliefs from which the attitudes, perceived behavioural control, subjective norms, and behavioural intentions were derived.

The present research has shown that Syrian farmers of FFV had favourable attitudes towards organic farming and were willing to convert their farms to organic within the next five years. The strong intention to convert to organic agriculture can be seen particularly among farmers who are already using many organic practices and low chemical inputs. These are good pre-conditions for further expansion of organic agriculture among Syrian farmers at a lower cost. Though Syrian farmers had positive intentions to convert to organic farming, initiatives of governmental institutions, NGOs and international development agencies about organic farming are important in spreading further information about conversion, certification, and quality requirements for their organic produce. Such initiatives should also pay particular attention to informing more about the continuously rising demand for fresh organic produce in regional and international markets, alongside with boosting farmers' perceptions and awareness of the economic, health and environmental benefits of producing FFV organically. These initiatives should not overlook or underestimate the important role that can be played by successful producers of organic FFV in the coastal region at helping and motivating farmers to convert their farms to certified organic FFV production. Farmers are inclined to have great trust in experience-based information provided by successful organic farmers. The role of wholesalers and exporters with interest in organic FFV can also be decisive in motivating farmers to start the conversion process by offering long term contracts [104]. The findings of this research yield implications for the different stakeholders (governmental institutions and NGOs, farmers, exporters, wholesalers, etc.) who are interested in prompting the Syrian export of organic products. In the pre-war period, the Syrian agricultural sector had been a significant source of income for many Syrian families who were engaged in producing, processing, trading and/or exporting agricultural products. The agricultural sector is likely the easiest sector to recover after the war in Syria reaches an end. Thus, once Syria is stabilised and the economic relationships with the EU are resumed, exporting organic FFV to the high-value EU markets (including Germany) under the EU Mediterranean Association 
Agreement, will indispensably offer great opportunities for Syria to acquire the foreign currency needed to help rebuild the post-war country.

Future research should explicitly consider two other factors that may also play an important role in the conversion to organic farming. First, the degree to which off-farm employment (by farmers and/or other household members) may affect the decision of farmers to adopt organic farming. Second, the possibility to convert only a part of the farm to organic farming. Many farmers are likely to consider an incremental step-by-step approach as part of their conversion strategy to organic farming. However, such an approach must be in line with national and (for export purposes) international regulations on organic agriculture.

Acknowledgments: We would like to thank the director and the staff of the Citrus Fruit Board, Tartous, Syria for their enormous and valuable support in data collection. We also thank Anne Christopherson for proofreading and copy-editing this paper.

Author Contributions: Irwa Issa and Ulrich Hamm conceived and designed the study together. Irwa Issa was responsible for the conduction of the survey with Syrian farmers. Irwa Issa designed and conducted the analysis with support of Ulrich Hamm. Irwa Issa wrote most parts of the paper. Ulrich Hamm contributed to the chapters "Introduction" and "Discussion and Conclusions".

Conflicts of Interest: The authors declare no conflict of interest.

\section{References and Note}

1. The World of Organic Agriculture: Statistics and Emerging Trends 2016; Willer, H.; Lernoud, J., Eds.; Research Institute of Organic Agriculture (FiBL): Frick, Switzerland, 2017.

2. Raynolds, L.T. The Globalization of organic agro-food networks. World Dev. 2004, 32, 725-743. [CrossRef]

3. Kledal, P.R.; Eyhorn, F.; van Elzakker, B.; de Figueiredo, E.A.P. The possibilities for inclusion of smallholder farmers in organic market chain development. In Organic Agriculture for Sustainable Livelihood; Halberg, N., Muller, A., Eds.; Earthscan (from Routledge): London, UK; New York, NY, USA, 2013; pp. 153-173.

4. Hermansen, J.E.; Knudsen, M.T.; Schader, C. Globalization of organic food chains and the environmental impacts. In Organic Agriculture for Sustainable Livelihood; Halberg, N., Muller, A., Eds.; Earthscan (from Routledge): London, UK; New York, NY, USA, 2013; pp. 55-73.

5. Sahota, A. The Global Market of Organic Food and Drink. In The World of Organic Agriculture: Statistics and Emerging Trends 2016; Research Institute of Organic Agriculture (FiBL): Frick, Switzerland, 2017; pp. 133-142.

6. MAAR. Syrian Agricultural Statistical Abstract 2009; Syrian Ministry of Agriculture (MAAR): Damascus, Syria, 2011.

7. CBS. Foreign Trade Summary from 2004 to 2011: Exports by Main Countries and Items; Syrian Bureau of Statistics: Damascus, Syria, 2015.

8. Offermann, F.; Nieberg, H.; Zander, K. Dependency of organic farms on direct payments in selected EU member states: Today and tomorrow. Food Policy 2009, 34, 273-279. [CrossRef]

9. Daugbjerg, C.; Tranter, R.; Hattam, C.; Holloway, G. Modelling the impacts of policy on entry into organic farming: Evidence from Danish-UK comparisons, 1989-2007. Land Use Policy 2011, 28, 413-422. [CrossRef]

10. Vairo, D.; Häring, A.M.; Dabbert, S.; Zanoli, R. Policies supporting organic food and farming in the EU: Assessment and development by stakeholders in 11 European countries. J. Int. Food Agribus. Mark. 2009, 21, 214-217. [CrossRef]

11. Constance, D.H.; Choi, J.Y. Overcoming the barriers to organic adoption in the United States: A look at pragmatic conventional producers in Texas. Sustainability 2010, 2, 163-188. [CrossRef]

12. Hamm, U.; Gronefeld, F. Organic marketing initiatives and rural development (OMIaRD). In The European Market for Organic Food: Revised and Updated Analysis; School of Management and Business, University of Wales: Aberystwyth, UK, 2004; ISBN 978-0-9543270-4-0.

13. Janssen, M.; Hamm, U. Governmental and private certification labels for organic food: Consumer attitudes and preferences in Germany. Food Policy 2014, 49, 437-448. [CrossRef]

14. De Cock, L. Determinants of Organic Farming Conversion. In Proceedings of the European Association of Agricultural Economists, the Future of Rural Europe in the Global Agri-Food System, Copenhagen, Denmark, 23-27 August 2005. 
15. Nemes, N. Comparative Analysis of Organic and Non-Organic Farming Systems: A Critical Assessment of Farm Profitability; Food and Agriculture Organization of the United Nations (FAO): Rome, Italy, 2009.

16. Peterson, H.H.; Barkley, A.P.; Chacon-Cascante, A.; Kastens, T.L. The motivation for organic grain farming in the United States: Profits, lifestyle, or the environment? J. Agric. Appl. Econ. 2012, 44, 137-155. [CrossRef]

17. Sgroi, F.; Candela, M.; Trapani, A.; Foderà, M.; Squatrito, R.; Testa, R.; Tudisca, S. Economic and financial comparison between organic and conventional farming in Sicilian lemon orchards. Sustainability 2015, 7, 947-961. [CrossRef]

18. Koesling, M.; Flaten, O.; Lien, G. Factors influencing the conversion to organic farming in Norway. Int. J. Agric. Resour. Gov. Ecol. 2008, 7, 78-95. [CrossRef]

19. Best, H. Environmental concern and the adoption of organic agriculture. Soc. Nat. Resour. 2010, 23, 451-468. [CrossRef]

20. Cranfield, J.; Henson, S.; Holliday, J. The motives, benefits, and problems of conversion to organic production. Agric. Hum. Values 2010, 27, 291-306. [CrossRef]

21. Lewis, D.J.; Barham, B.L.; Robinson, B. Are there spatial spillovers in the adoption of clean technology? The case of organic dairy farming. Land Econ. 2011, 87, 250-267. [CrossRef]

22. Läpple, D.; Rensburg, T.V. Adoption of organic farming: Are there differences between early and late adoption? Ecol. Econ. 2011, 70, 1406-1414. [CrossRef]

23. Schmidtner, E.; Lippert, C.; Engler, B.; Häring, A.M.; Aurbacher, J.; Dabbert, S. Spatial distribution of organic farming in Germany: Does neighbourhood matter? Eur. Rev. Agric. Econ. 2012, 39, 661-683. [CrossRef]

24. Sutherland, L.-A. Can organic farmers be 'good farmers'? Adding the 'taste of necessity' to the conventionalization debate. Agric. Hum. Values 2013, 30, 429-441. [CrossRef]

25. Best, H. Organic agriculture and the conventionalization hypothesis: A case study from West Germany. Agric. Hum. Values 2008, 25, 95-106. [CrossRef]

26. Darnhofer, I.; Schneeberger, W.; Freyer, B. Converting or not converting to organic farming in Austria: Farmer types and their rationale. Agric. Hum. Values 2005, 22, 39-52. [CrossRef]

27. Stolze, M.; Jahrl, I. Assessment of Organic Farming Policy Measures and Strategies in Six Case Study Countries: Contribution of Public Support Measures Addressing Organic Farming to the Development of the Organic Sector. In Use and Efficiency of Public Support Measures Addressing Organic Farming; Johann Heinrich von Thünen-Institut (vTI); Institute of Farm Economics: Braunschweig, Germany, 2011; pp. 67-92.

28. Freyer, B.; Bingen, J.; Klimek, M. Ethics in the organic movement. In Re-Thinking Organic Food and Farming in a Changing World; Freyer, B., Bingen, J., Eds.; The International Library of Environmental; Agricultural and Food Ethics; Springer: Dordrecht, The Netherlands, 2015; Volume 22, pp. 13-39, ISBN 978-94-017-9189-2.

29. Mzoughi, N. Farmers adoption of integrated crop protection and organic farming: Do moral and social concerns matter? Ecol. Econ. 2011, 70, 1536-1545. [CrossRef]

30. Thamaga-Chitja, J.; Hendriks, S.L. Emerging issues in smallholder organic production and marketing in South Africa. Dev. South. Afr. 2008, 25, 317-326. [CrossRef]

31. Karki, L.; Schleenbecker, R.; Hamm, U. Factors influencing a conversion to organic farming in Nepalese tea farms. J. Agric. Rural Dev. Trop. Subtrop. 2011, 112, 113-123.

32. Buerkert, A.; Schlecht, E. Organic agriculture in developing countries: Status quo and challenges. Rural 21 Int. J. Rural Dev. 2017, 3, 6-8.

33. Schoonbeek, S.; Azadi, H.; Mahmoudi, H.; Derudder, B.; De Maeyer, P.; Witlox, F. Organic agriculture and undernourishment in developing countries: Main potentials and challenges. Crit. Rev. Food Sci. Nutr. 2013, 53, 917-928. [CrossRef] [PubMed]

34. Isin, F.; Cukur, T.; Armagan, G. Factors affecting the adoption of the organic dried fig agriculture system in Turkey. J. Appl. Sci. 2007, 7, 748-754.

35. Radwan, A.; Diab, Y.A.A.; Abo-Nahoul, M.A. Determinants of the adaption of organic agriculture in Egypt using a duration analysis technique. In Proceedings of the 85th Agricultural Economic Society Annual Conference, Warwick University, Coventry, UK, 18-20 April 2011; pp. 1-12.

36. Thapa, G.B.; Rattanasuteerakul, K. Adoption and extent of organic vegetable farming in Mahasarakham province, Thailand. Appl. Geogr. 2011, 31, 201-209. [CrossRef]

37. Rana, S.; Parvathi, P.; Waibel, H. Factors affecting the adoption of organic pepper farming in India. In Proceedings of the Tropentag, Resilience of Agricultural Systems Against Crises, Göttingen and Kassel/Witzenhausen, Germany, 19-21 September 2012. 
38. Kleemann, L.; Abdulai, A. Organic certification, agro-ecological practices and return on investment: Evidence from pineapple producers in Ghana. Ecol. Econ. 2013, 93, 330-341. [CrossRef]

39. Azam, M.S.; Banumathi, M. The role of demographic factors in adopting organic farming: A logistic model approach. Int. J. 2015, 3, 713-720.

40. Patidar, S.; Patidar, H. A study of perception of farmers towards organic farming. Int. J. Appl. Innov. Eng. Manag. 2015, 4, 269-277.

41. Jouzi, Z.; Azadi, H.; Taheri, F.; Zarafshani, K.; Gebrehiwot, K.; Van Passel, S.; Lebailly, P. Organic farming and small-scale farmers: Main opportunities and challenges. Ecol. Econ. 2017, 132, 144-154. [CrossRef]

42. Sarker, M.A.; Itohara, Y.; Hoque, M. Determinants of adoption decisions: The case of organic farming (OF) in Bangladesh. Ext. Farming Syst. J. 2009, 5, 39-46.

43. Pornpratansombat, P.; Bauer, B.; Boland, H. The adoption of organic rice farming in Northeastern Thailand. J. Org. Syst. 2011, 6, 4-12.

44. Demiryürek, K.; Ceyhan, V.; Bozoğlu, M. Risk attitudes of organic and conventional hazelnut producers in Turkey. Hum. Ecol. Risk Assess. Int. J. 2012, 18, 471-482. [CrossRef]

45. Alzaidi, A.A.; Baig, M.B.; Elhag, E.A. An investigation into the farmers' attitudes towards organic farming in Riyadh Region-Kingdom of Saudi Arabia. Bulg. J. Agric. Sci. 2013, 19, 426-431.

46. Shaban, A. Factors influencing farmers' decision to shift to organic farming: The case of Gaza Strip. Br. J. Econ. Manag. Trade 2015, 5, 78-87. [CrossRef]

47. IFAD. Egypt: Smallholder Contract Farming for High-Value and Organic Agricultural Exports; International Fund for Agricultural Development (IFAD): Near East and North Africa Division; Programme Management Department: Rome, Italy, 2009.

48. Bolwig, S.; Gibbon, P.; Jones, S. The Economics of smallholder organic contract farming in tropical Africa. World Dev. 2009, 37, 1094-1104. [CrossRef]

49. Oelofse, M.; Høgh-Jensen, H.; Abreu, L.S.; Almeida, G.F.; Hui, Q.Y.; Sultan, T.; de Neergaard, A. Certified organic agriculture in China and Brazil: Market accessibility and outcomes following adoption. Ecol. Econ. 2010, 69, 1785-1793. [CrossRef]

50. Hattam, C.E.; Lacombe, D.J.; Holloway, G.J. Organic certification, export market access and the impacts of policy: Bayesian estimation of avocado smallholder "times-to-organic certification" in Michoacán Mexico. Agric. Econ. 2012, 43, 441-457. [CrossRef]

51. Goldberger, J.R. Non-governmental organizations, strategic bridge building, and the "scientization" of organic agriculture in Kenya. Agric. Hum. Values 2008, 25, 271-289. [CrossRef]

52. Nelson, E.; Gómez Tovar, L.; Schwentesius Rindermann, R.; Gómez Cruz, M.Á. Participatory organic certification in Mexico: An alternative approach to maintaining the integrity of the organic label. Agric. Hum. Values 2010, 27, 227-237. [CrossRef]

53. Kirchner, C. Overview of Participatory Guarantee Systems in 2014. In The World of Organic Agriculture: Statistics and Emerging Trends 2015; Research Institute of Organic Agriculture (FiBL): Frick, Switzerland, 2015; pp. 134-136.

54. Oyesola, O.B.; Obabire, I.E. Farmers' perception of organic farming in selected local government areas of Ekiti State, Nigeria. J. Org. Syst. 2011, 6, 20-26.

55. Lee, S.; Nguyen, T.; Poppenborg, P.; Shin, H.-J.; Koellner, T. Conventional, partially converted and environmentally friendly farming in South Korea: Profitability and factors affecting farmers' choice. Sustainability 2016, 8, 704. [CrossRef]

56. Mahindarathne, P.P.; Gunaratne, L.H.P. Entrepreneurial orientation of organic farmers: A case of organic vegetable farmers in the Badulla district of Sri Lanka. J. Int. Food Agribus. Mark. 2015, 27, 324-336. [CrossRef]

57. Sarker, M.A.; Itohara, Y. Factors Influencing the Extent of Practice of Organic Farming Technologies: A Case Study of Tangail District in Bangladesh. Am. J. Agric. Biol. Sci. 2008, 3, 584-590. [CrossRef]

58. Ullah, A.; Shah, S.N.M.; Ali, A.; Naz, R.; Mahar, A.; Kalhoro, S.A. Factors affecting the adoption of organic farming in Peshawar-Pakistan. Agric. Sci. 2015, 6, 587-593. [CrossRef]

59. Naspetti, S.; Bteich, M.R.; Pugliese, P.; Salame, N. Motivation and values of farmers in Lebanon: A comparison between organic and conventional agricultural producers. New Medit Mediterr. J. Econ. Agric. Environ. 2016, 15, 70-80.

60. Blackman, A.; Naranjo, M.A. Does eco-certification have environmental benefits? Organic coffee in Costa Rica. Ecol. Econ. 2012, 83, 58-66. [CrossRef] 
61. Ramos, M.R.; Favaretto, N.; Dieckow, J.; Dedeck, R.A.; Vezzani, F.M.; de Almeida, L.; Sperrin, M. Soil, water and nutrient loss under conventional and organic vegetable production managed in small farms versus forest system. J. Agric. Rural Dev. Trop. Subtrop. 2014, 115, 31-40.

62. Wollni, M.; Andersson, C. Spatial patterns of organic agriculture adoption: Evidence from Honduras. Ecol. Econ. 2014, 97, 120-128. [CrossRef]

63. Chappell, M.J.; LaValle, L.A. Food security and biodiversity: Can we have both? An agroecological analysis. Agric. Hum. Values 2011, 28, 3-26. [CrossRef]

64. Miniard, P.W.; Cohen, J.B. Modeling personal and normative influences on behavior. J. Consum. Res. 1983, 10, 169-180. [CrossRef]

65. Bandura, A. Organisational applications of social cognitive theory. Aust. J. Manag. 1988, 13, $275-302$. [CrossRef]

66. Ajzen, I. The theory of planned behavior. Organ. Behav. Hum. Decis. Process. 1991, 50, 179-211. [CrossRef]

67. Ajzen, I. Attitudes, Personality and Behaviour, 2nd ed.; Open University Press/McGraw-Hill: Milton-Keynes, UK, 2005.

68. Madden, T.J.; Ellen, P.S.; Ajzen, I. A comparison of the theory of planned behavior and the theory of reasoned action. Pers. Soc. Psychol. Bull. 1992, 18, 3-9. [CrossRef]

69. Wauters, E.; Bielders, C.; Poesen, J.; Govers, G.; Mathijs, E. Adoption of soil conservation practices in Belgium: An examination of the theory of planned behaviour in the agri-environmental domain. Land Use Policy 2010, 27, 86-94. [CrossRef]

70. Staats, H.; Jansen, L.; Thøgersen, J. Greening the greenhouse grower: A behavioral analysis of a sector-initiated system to reduce the environmental load of greenhouses. J. Environ. Manag. 2011, 92, 2461-2469. [CrossRef] [PubMed]

71. Martínez-García, C.G.; Dorward, P.; Rehman, T. Factors influencing adoption of improved grassland management by small-scale dairy farmers in central Mexico and the implications for future research on smallholder adoption in developing countries. Livest. Sci. 2013, 152, 228-238. [CrossRef]

72. Baumgart-Getz, A.; Prokopy, L.S.; Floress, K. Why farmers adopt best management practice in the United States: A meta-analysis of the adoption literature. J. Environ. Manag. 2012, 96, 17-25. [CrossRef] [PubMed]

73. Meijer, S.S.; Catacutan, D.; Sileshi, G.W.; Nieuwenhuis, M. Tree planting by smallholder farmers in Malawi: Using the theory of planned behaviour to examine the relationship between attitudes and behaviour. J. Environ. Psychol. 2015, 43, 1-12. [CrossRef]

74. Deng, J.; Sun, P.; Zhao, F.; Han, X.; Yang, G.; Feng, Y. Analysis of the ecological conservation behavior of farmers in payment for ecosystem service programs in eco-environmentally fragile areas using social psychology models. Sci. Total Environ. 2016, 550, 382-390. [CrossRef] [PubMed]

75. Yazdanpanah, M.; Hayati, D.; Hochrainer-Stigler, S.; Zamani, G.H. Understanding farmers' intention and behavior regarding water conservation in the Middle-East and North Africa: A case study in Iran. J. Environ. Manag. 2014, 135, 63-72. [CrossRef] [PubMed]

76. Borges, J.A.R.; Lansink, A.G.J.M.O.; Ribeiro, C.M.; Lutke, V. Understanding farmers' intention to adopt improved natural grassland using the theory of planned behavior. Livest. Sci. 2014, 169, 163-174. [CrossRef]

77. Tutkun, A.; Lehmann, B.; Schmidt, P. Explaining the Conversion to Organic Farming of Farmers of the Obwalden Canton, Switzerland-Extension of the Theory of Planned Behavior within a Structural Equation Modeling Approach. In Proceedings of the International Association of Agricultural Economists (IAAE) > 2006 Annual Meeting, Queensland, Australia, 12-18 August 2006.

78. Hattam, C.E. Adopting Certified Organic Production: Evidence from Small-Scale Avocado Producers in Michoacán, Mexico. Ph.D. Thesis, University of Reading, Reading, UK, June 2006.

79. Kaufmann, P.; Stagl, S.; Franks, D.W. Simulating the diffusion of organic farming practices in two New EU Member States. Ecol. Econ. 2009, 68, 2580-2593. [CrossRef]

80. Läpple, D. The Adoption of Organic Farming: An Empirical Investigation of the Irish Drystock Sector. Ph.D. Thesis, National University of Ireland, Galway, UK, June 2010.

81. Sutherland, L.-A. "Effectively organic": Environmental gains on conventional farms through the market? Land Use Policy 2011, 28, 815-824. [CrossRef]

82. Asadollahpour, A.; Najafabadi, M.O.; Hosseini, S.J. Modeling behavior pattern of Iranian organic paddy farmers. Paddy Water Environ. 2016, 14, 221-229. [CrossRef] 
83. Krueger, N.F.; Reilly, M.D.; Carsrud, A.L. Competing models of entrepreneurial intentions. J. Bus. Ventur. 2000, 15, 411-432. [CrossRef]

84. Läpple, D.; Kelley, H. Understanding the uptake of organic farming: Accounting for heterogeneities among Irish farmers. Ecol. Econ. 2013, 88, 11-19. [CrossRef]

85. Fishbein, M.; Ajzen, I. Predicting and Changing Behavior: The Reasoned Action Approach; Taylor \& Francis: Milton Park, Didcot, UK; Psychology Press: New York, NY, USA, 2010; ISBN 978-1-136-87473-4.

86. Ajzen, I.; Fishbein, M. The influence of attitudes on behavior. In The Handbook of Attitudes; Albarracin, D., Johnson, B.T., Zanna, M.P., Eds.; Lawrence Erlbaum Associates: Mahwah, NJ, USA, 2005; pp. 173-221.

87. Fishbein, M. An Investigation of the relationships between beliefs about an object and the attitude toward that object. Hum. Relat. 1963, 16, 233-239. [CrossRef]

88. Citrus Fruit Board Database of Citrus Fruit Board; MAAR: Tartous, Syria, 2011.

89. Burns, A.C.; Bush, R.F. Marketing Research, 6th ed.; Prentice Hall: Upper Saddle River, NJ, USA; London, UK, 2010; ISBN 978-0-13-713599-8.

90. Bryman, A. Social Research Methods, 4th ed.; Oxford University Press: Oxford, UK, 2012; ISBN 978-0-19-958805-3.

91. Ringle, C.M.; Wende, S.; Becker, J.-M. SmartPLS 3-The Software for the Next Generation of PLS Path Modeling; SmartPLS GmbH: Boenningstedt, Germany, 2015.

92. Hair, J.J.F.; Hult, G.T.M.; Ringle, C.; Sarstedt, M. A Primer on Partial Least Squares Structural Equation Modeling (PLS-SEM), 1st ed.; Sage Publications, Inc.: Los Angeles, CA, USA, 2014; ISBN 978-1-4522-1744-4.

93. Bollen, K.A. Structural Equations with Latent Variables; John Wiley \& Sons: Hoboken, NJ, USA, 1989; ISBN 978-0-471-01171-2.

94. Reinartz, W.; Haenlein, M.; Henseler, J. An empirical comparison of the efficacy of covariance-based and variance-based SEM. Int. J. Res. Mark. 2009, 26, 332-344. [CrossRef]

95. Henseler, J.; Ringle, C.M.; Sinkovics, R.R. The use of partial least squares path modeling in international marketing. New Challenges to International Marketing. In Advances in International Marketing; Sinkovics, R.R., Ghauri, P.N., Eds.; Emerald Group Publishing Limited: Bingley, UK, 2009; Volume 20, pp. 277-319, ISBN 978-1-84855-468-9.

96. Bollen, K.A.; Bauldry, S. Three Cs in measurement models: Causal indicators, composite indicators, and covariates. Psychol. Methods 2011, 16, 265-284. [CrossRef] [PubMed]

97. Henseler, J. Bridging design and behavioral research with variance-based structural equation modeling. J. Advert. 2017, 46, 178-192. [CrossRef]

98. NAPC. The state of food and agriculture state in Syria 2013. In The State of Food and Agriculture State in Syria; National Agricultural Policy Centre (NAPC): Damascus, Syria, 2015.

99. NAPC. Tomatoes perspectives in Syria: Commodity brief No. 12. 2015.

100. Dijkstra, T.K.; Henseler, J. Consistent partial least squares path modeling. Manag. Inf. Syst. Q. 2015, 39, 297-316. [CrossRef]

101. Dijkstra, T.K.; Henseler, J. Consistent and asymptotically normal PLS estimators for linear structural equations. Comput. Stat. Data Anal. 2015, 81, 10-23. [CrossRef]

102. Henseler, J.; Ringle, C.M.; Sarstedt, M. A new criterion for assessing discriminant validity in variance-based structural equation modeling. J. Acad. Mark. Sci. 2015, 43, 115-135. [CrossRef]

103. Terano, R.; Mohamed, Z.; Shamsudin, M.N.; Latif, I.A. Factors influencing intention to adopt sustainable agriculture practices among paddy farmers in Kada, Malaysia. Asian J. Agric. Res. 2015, 9, 268-275. [CrossRef]

104. Issa, I. Analysis of the Market Potential of Syrian Organic Fruit and Vegetables for Exports to Germany. Ph.D. Thesis, University of Kassel, Kassel, Germany, 19 October 2016.

(C) 2017 by the authors. Licensee MDPI, Basel, Switzerland. This article is an open access article distributed under the terms and conditions of the Creative Commons Attribution (CC BY) license (http://creativecommons.org/licenses/by/4.0/). 